\title{
The Relationship between the Mean Surface Air Temperature in Egypt and NAO Index and ENSO
}

\author{
Y.Y. Hafez ${ }^{*}$ and S.M. Robaa
}

Astronomy \& Meteorology Department, Faculty of Science, Cairo University, Giza, Egypt, 12613

\begin{abstract}
The relationship between the NAO index and ENSO and the mean surface air temperature over Egypt has been investigated. The NCEP/NCAR reanalysis data of the monthly mean surface air temperature over Egypt for the period (1948-2005) have been used in this study. The corresponding monthly mean values of NAO index, SOI, and El-Nino3 have been also used. Monte Carlo methodology as a linear correlation analysis has been used to obtain the correlation coefficient between the mean surface air temperature over Egypt and NAO, SOI, and El-Nino3 through the period (19482005). The results show that surface air temperature in Egypt is significantly correlated with the climatic index NAO and ENSO only for a south western part of Egypt. There is a significant negative correlation (-0.6) between surface air temperature over south west part of Egypt in winter season and NAO index. The relationship between EL-Nino3 and surface air temperature has contradicted the relationship with SOI. Whereas, a significant positive correlation $(+0.6)$ between surface air temperature over south west part of Egypt and EL-Nino3 in autumn season. Surface air temperature correlated with SOI by a significant negative correlation (-0.5) during the same season over south west of Egypt. It is concluded that the surface air temperature is significantly correlated with NAO index and ENSO over the south west part of Egypt.
\end{abstract}

Keywords: Surface air temperature, NAO index, EL-Nino3, SOI, ENSO.

\section{INTRODUCTION}

The North Atlantic Oscillation (NAO) is one of the major modes of variability of the Northern Hemisphere atmosphere. The NAO index is defined as the pressure gradient between Greenland and the Azores and describes the zonality of the flow in the North Atlantic region. i.e., NAO is the difference of the normalized sea level pressures between Ponta Delgada, Azores and Reykjavik, Iceland. A permanent low-pressure system over Iceland (the Icelandic Low) and a permanent high-pressure system over the Azores (the Azores High) control the direction and strength of westerly winds into Europe. The relative strengths and positions of these systems vary from year to year and this variation is known as the NAO. A large difference in the pressure at the two locations (a high index year, denoted $\mathrm{NAO}+$ ) leads to increased westerlies and, consequently, cool summers and mild and wet winters in Central Europe and its Atlantic facade. In contrast, if the index is low (NAO-), westerlies are suppressed, these areas suffer cold winters and storms track southerly toward the Mediterranean Sea.

The NAO can be seen as a reflection of the fluctuation of the normal winter tropospheric flow in the northern hemisphere [1-7]. Many studies revealed that ENSO influences the climate in many regions around the globe. The variations in low-latitude circulation and extreme climatic events in the tropical Americas, global and regional scale precipitation patterns associated with the El Nino/Southern Oscillation have been also investigated in many studies [8-12].

The Southern Oscillation Index (SOI) is defined as the difference between sea level pressure at Tahiti $\left(145^{\circ} \mathrm{W}\right.$ and

\footnotetext{
*Address correspondence to this author at the Astronomy \& Meteorology Department, Faculty of Science, Cairo University, Giza, Egypt, 12613; E-mail:d_hafez@hotmail.com
}

$\left.18^{\circ} \mathrm{S}\right)$ and Darwin $\left(135^{\circ} \mathrm{E}\right.$ and $\left.16^{\circ} \mathrm{S}\right)$. SOI is coupled with EL-Nino3. Whereas, El-Nino is the name given to the phenomenon, which occurs when sea-surface temperatures (SSTs) in the equatorial Pacific Ocean off the South American coast becomes warmer than normal. Nino3 is defined as the sea surface temperature at the Pacific Ocean in the region $\left(90^{\circ} \mathrm{W}-150^{\circ} \mathrm{W}, 5^{\circ} \mathrm{S}-5^{\circ} \mathrm{N}\right)[13]$.

Many scientific literatures show that the El NinoSouthern Oscillation (ENSO) has a significant influence on climate in many parts of the globe [14] concluded that El Nino-Southern Oscillation and North Atlantic Oscillation control of climate in Puerto Rico. They examined the possible impact of ENSO on climatic patterns on the island of Puerto Rico in the Caribbean. Their result revealed that the annual mean air temperatures were controlled by ENSO. They also found that, during years of a high winter NAO index, the annual precipitation in Puerto Rico was lower than average. Another literatures studied the atmospheric relationship and wintertime temperature and precipitation in the Eastern Mediterranean region including Egypt e.g. [15-17]. Almost of the previous studies of the surface temperature fluctuations over Egypt had used the station data. Unfortunately, the available station data of the surface temperature for Egypt is not homogenous and not caver all of Egypt.

Although many statistical connections between El Nino/Southern Oscillation (ENSO) events and climatic impacts around the world have been found, [9-12, 14, 18-25], the effect of ENSO on mean surface air temperature over Egypt did not investigate yet. The present work aims to investigate the connection between the seasonal and annual mean surface air temperature over Egypt with climatic indices NAO, El-Nino3 and SOI through the period of (19482005). Whereas, determination of the areas of Egypt that influenced by the climatic changes are very important of sustainable development processes in Egypt. 


\section{DATA}

The NCEP/NCAR Reanalysis project is using a state-ofthe-art analysis/forecast system to perform data assimilation using past data from 1948 to 2005. Data of the monthly mean surface air temperature composite over Egypt have been obtained for the period (1948-2005) from the Web site http: //www.cdc.noaa.gov/. The data has been provided by the NOAA/OAR/ESRL PSD, Boulder, Colorado, USA, and [26]. Furthermore, the corresponding monthly mean values of NAO index, SOI, and El-Nino3 have been obtained from the same web site and also used in the present work.

\section{METHODOLOGY}

\section{A. Calculation of Seasonal and Annual Averages}

For each grid point in the domain of Egypt, seasonal and annual averages for surface temperature have been calculated using of the NCEP/NECAR reanalysis monthly data sets and using of statistical mean average (i.e. (Dec. + Jan.+ Feb.)/3) for winter season, mean of Mar., Apr., and May months for spring and so on for summer and autumn seasons through the period of (1948-2005). The annual composite mean comes from the statistical mean for 12 months from Jan. to Dec. for the period of study. The seasonal and annual values of NAO index, SOI, and El-Nino3 have been calculated in the same manner; in fact ENSO phenomenon is the combination of SOI and El-Nino3.

\section{B. Anomalies Methodology}

The anomaly in the mean surface air temperature (seasonal or annual) is $\left(\mathrm{A}^{\prime}\right)$ for each grid point in the domain of study through the period of study (1948-2005). This anomaly is calculated as the difference of the mean of (seasonal or annual) surface air temperature (A) and its climatic mean value $(\bar{A})$ for each grid point. Whereas, the climatic mean values for the surface air temperature have been taken through the period (1968-1996).

\section{Local Significance and Calculation of Correlation Pat- terns}

For a given seasonally and annually resolved means surface air temperature time series at each grid point is correlated with the climatic index (NAO, El-Nino3 and SOI) time series. Each grid point correlation is t-tested for local significance using [27], allowing for temporal autocorrelation according to [28] method. For field significance, the areal extent of locally significant correlations in a correlation map must exceed the areal extent that can be expected by chance. To estimate the correlation, we use the Monte Carlo methodology. The field-significance statistic is the area-weighted average absolute correlation of a given correlation maps (considering only the locally significant correlations). The field-significance threshold is the 95th percentile of a 1000member Monte-Carlo population.

\section{Linear Correlation Method}

For a linear correlation analysis of the climatic indices NAO, SOI, and El-Nino3 datasets and the mean surface air temperature over Egypt during the study period (1948-2005), the methodology of Monte Carlo has been used [28]. Based on this methodology a correlation of $+/-0.3$ would be significant. These significance levels are local for a resolution of $144 \times 73$ grid points (the resolution of the temperature dataset). One would assume at least $0.05 \times(144 * 73)=526$ grids would be significant by chance at the one-sided $95 \%$ level (At website http: //www.cdc.noaa.gov/Correlation/significance.html).

\section{RESULTS}

The seasonal and annual surface air temperatures over Egypt have been analyzed. The distribution of maximum and minimum seasonal and annual mean surface air temperatures composite and their locations over Egypt during the period 1948-2005 have been given in Table 1 and Fig. (1). In fact the distribution of maximum and minimum temperature is very important for determine the more convenient regions for economy and agriculture development process in Egypt. It was observed that the mean surface air varies from season to season during the study period. The maximum seasonal mean air temperature $\left(33^{\circ} \mathrm{C}\right)$ has been occurred during summer season at the south east part of Egypt. Meanwhile, the minimum seasonal mean air temperature $\left(11^{\circ} \mathrm{C}\right)$ has been occurred during winter season at the north east part of Egypt. The ranges of seasonal air temperature value are (11 and $\left.19^{\circ} \mathrm{C}\right),\left(18\right.$ and $\left.26^{\circ} \mathrm{C}\right),\left(25\right.$ and $\left.33^{\circ} \mathrm{C}\right),\left(20\right.$ and $\left.28^{\circ} \mathrm{C}\right)$, and $(20$ and $27^{\circ} \mathrm{C}$ ) during winter, spring, summer, autumn and annual respectively, (Table 1 and Fig. (1)).

The analysis of the surface air temperature using of anomalies methodology can approaches the climatic changes and may be it is more liable rather than Principal Component Analysis (PCA) or the time series methodologies to observe regional warming and cool changes in Egypt through the whole period of study. Table $\mathbf{2}$ and Fig. (2) show the

Table 1. The Distribution of Maximum and Minimum Seasonal and Annual Mean Surface Air Temperature Composite and their Locations over Egypt during the Period 1948-2005

\begin{tabular}{|c|c|c|c|c|}
\hline \multicolumn{2}{|c|}{ Minimum Temperature } & \multicolumn{2}{c|}{ Maximum Temperature } & \multirow{2}{*}{ Temperature Season } \\
\hline Location in Egypt & Value ${ }^{\left.{ }^{\circ} \mathbf{C}\right)}$ & Location in Egypt & 19 & Value $\left({ }^{\circ} \mathbf{C}\right)$ \\
\hline \hline North East & 11 & South East & 26 & Winter \\
\hline North & 18 & South & 33 & Spring \\
\hline North & 25 & South East & 28 & Summer \\
\hline North East & 20 & South East & 27 & Antumn \\
\hline North & 20 & South East & & Annual \\
\hline
\end{tabular}


(a)

NCEP/NCAR Rennalysis

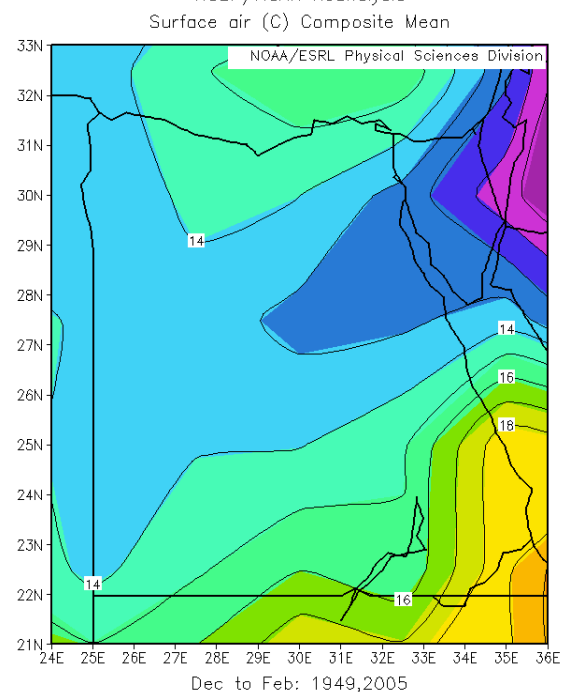

(c)

NCEP/NCAR Reanalysis

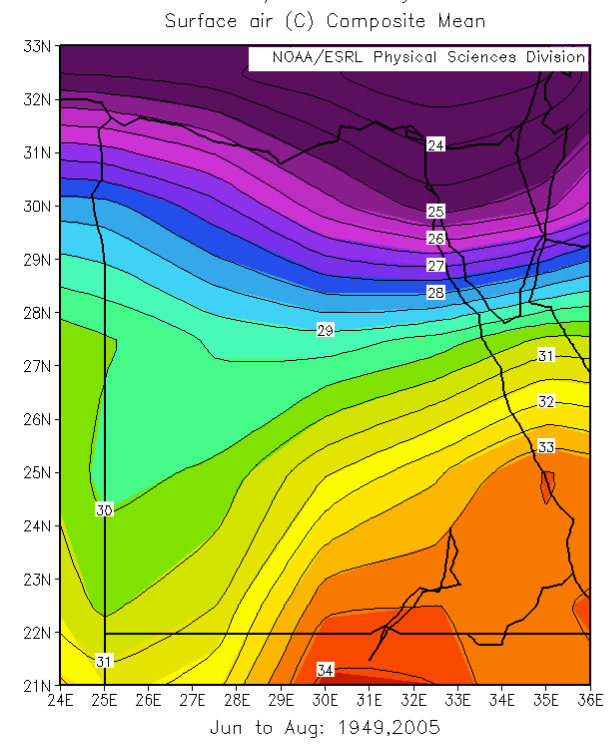

(b)

NCEP/NCAR Reanalysis

Surface air (C) Composite Mean
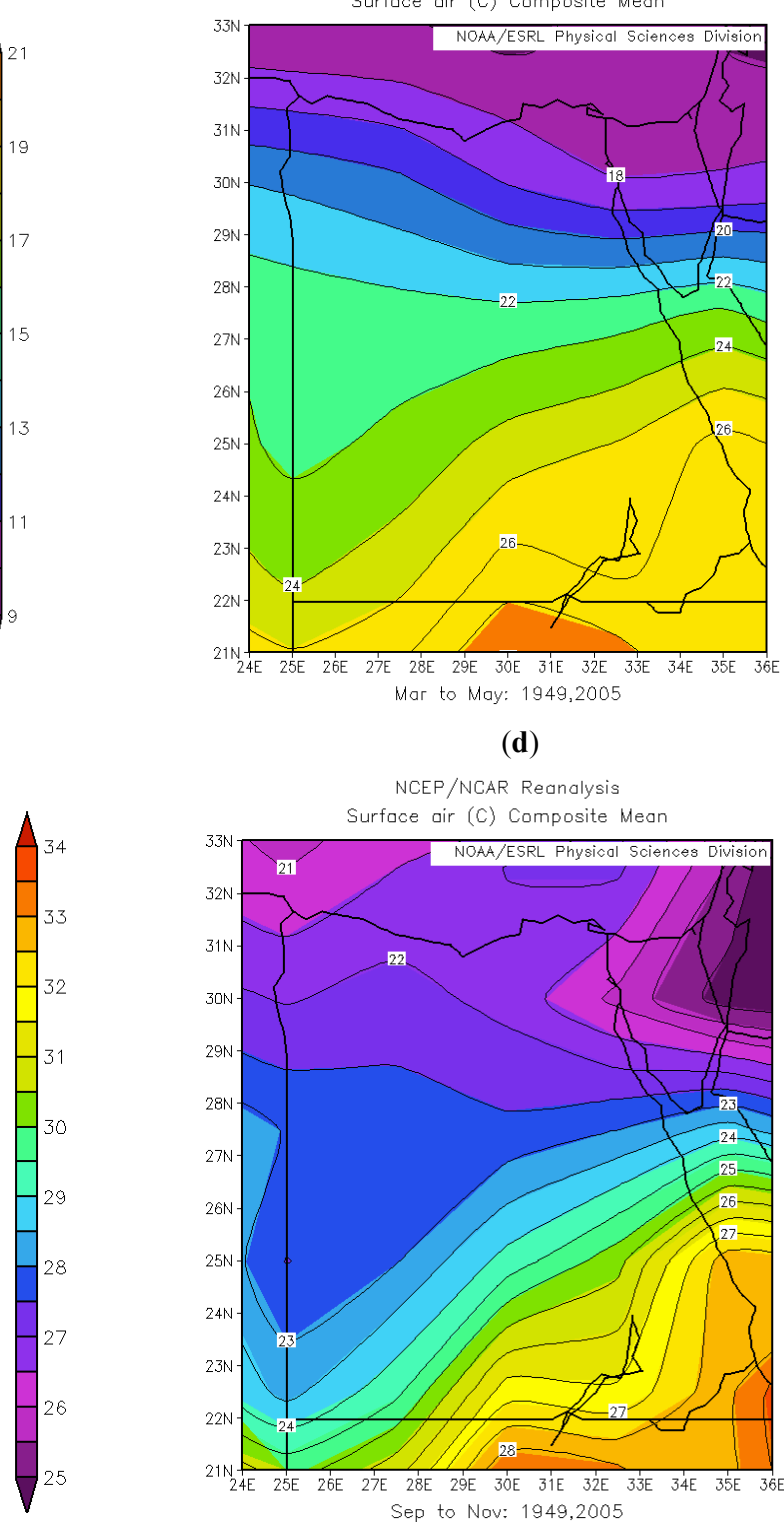

(d)

NCEP/NCAR Reanalysis

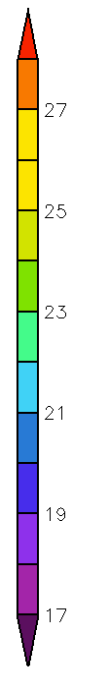

Surface air (C) Composite Mean
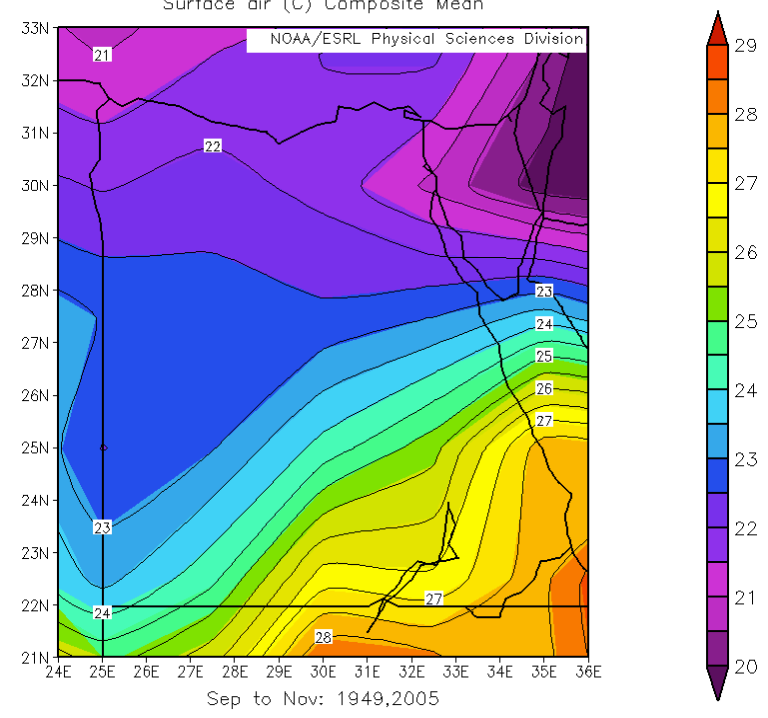

(e)

NCEP/NCAR Reunalysis

Surfoce air (C) Composite Mean

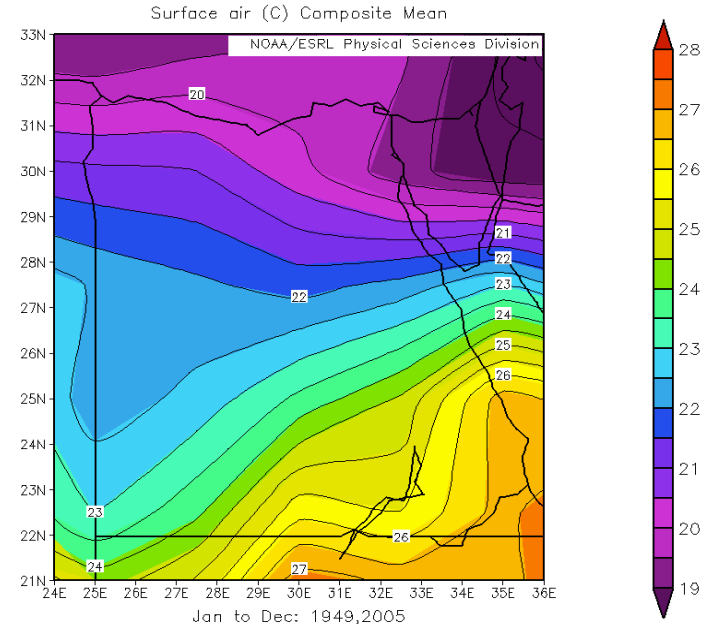

Fig. (1). The distribution of seasonal and annual mean surface air temperature composite over Egypt during the period 1948-2005. (a) Winter, (b) Spring, (c) Summer, (d) Autumn and (e) Annual. 
(a)

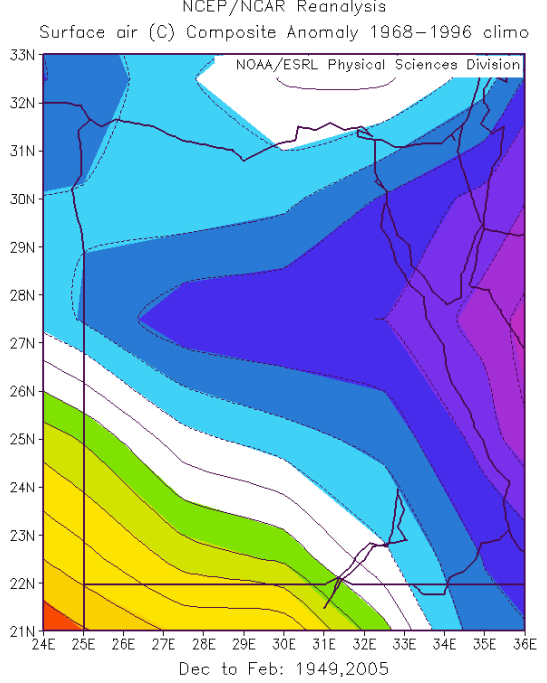

(c)

NCEP/NCAR Regnalysis

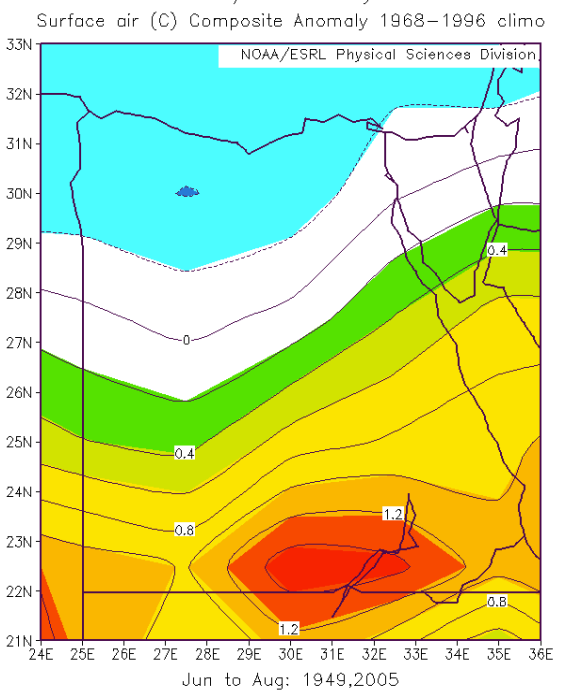

(b)

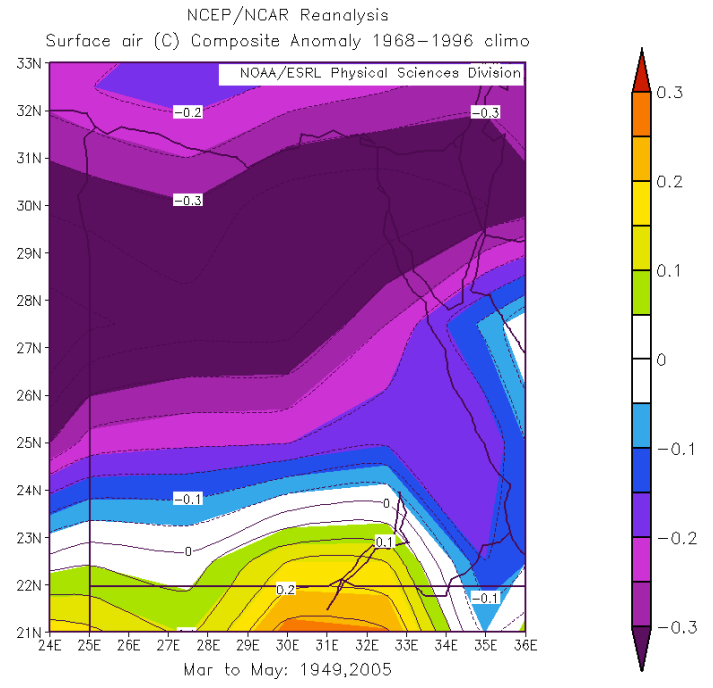

(d)

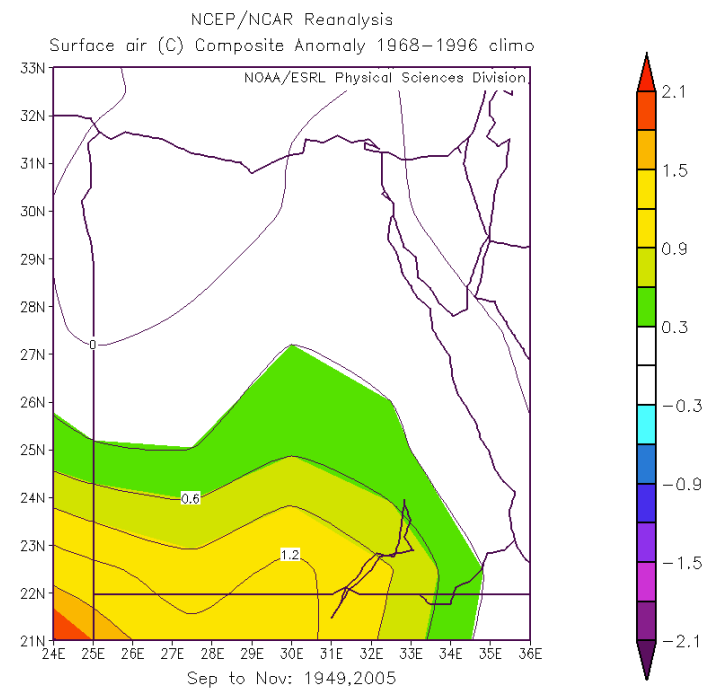

(e)

NCEP/NCAR Reanalysis

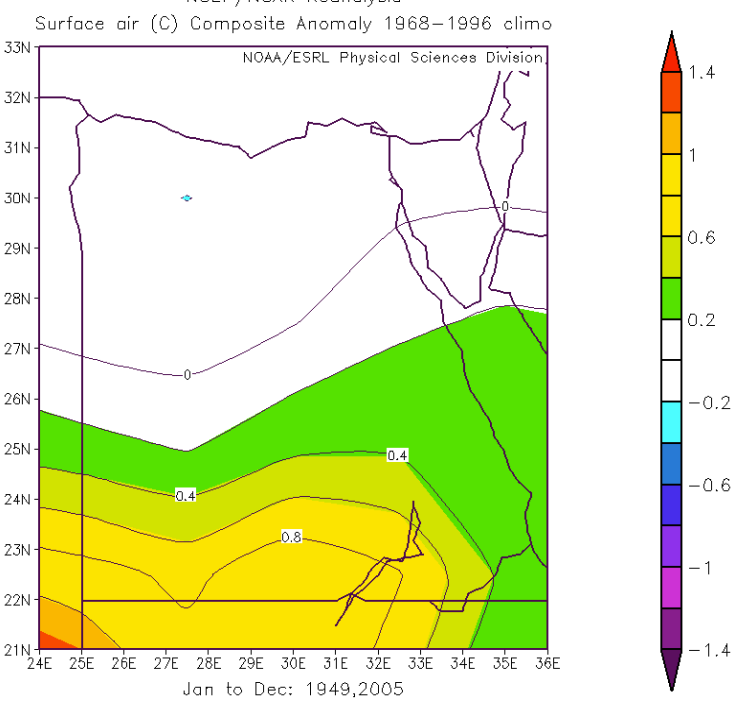

Fig. (2). The distribution of seasonal and annual mean surface air temperature composite anomalies over Egypt during the period 1948-2005. (a) Winter, (b) Spring, (c) Summer, (d) Autumn and (e) Annual. 
Table 2. The Distribution of Positive and Negative of Seasonal and Annual Mean Surface Air Temperature Composite Anomalies and their Locations over Egypt during the Period 1948-2005

\begin{tabular}{|c|c|c|c|c|}
\hline \multicolumn{2}{|c|}{ Minimum Negative } & \multicolumn{2}{c|}{ Maximum Positive } & \multirow{2}{*}{ Temperature Anomaly Season } \\
\cline { 1 - 4 } Location in Egypt & Value $\left({ }^{\circ} \mathbf{C}\right)$ & Location in Egypt & Value $\left({ }^{\circ} \mathbf{C}\right)$ & Winter \\
\hline \hline North-East & -0.4 & South West & +0.5 & Spring \\
\hline North & -0.3 & South & +0.1 & Summer \\
\hline North & -0.2 & South & +1.2 & Autumn \\
\hline North West & -0.1 & South West & +0.8 & Annual \\
\hline North & -0.1 & South & & \\
\hline
\end{tabular}

distribution of seasonal and annual mean surface air temperature composite anomalies and their locations over Egypt during the study period 1948-2005. It is noticed that there is a distinct warming over most of the southern parts of Egypt while the northern parts are characterized by existence of cooling. The maximum warming $\left(+1.2^{\circ} \mathrm{C}\right)$ has been found during both summer and autumn seasons over south and south-west parts respectively while the maximum cooling $\left(-0.4^{\circ} \mathrm{C}\right)$ has been found during winter season over north and east parts of Egypt. Furthermore, the annual mean of maximum positive anomalies $\left(+0.8^{\circ} \mathrm{C}\right)$ observed over the southern Egypt. Annual mean value of maximum positive $\left(+0.8^{\circ} \mathrm{C}\right)$ and minimum negative $\left(-0.1^{\circ} \mathrm{C}\right)$ anomalies occur mainly over south and north parts of Egypt respectively. The contradicting in the annual mean surface air temperature anomalies verifies the above obtained results.

\subsection{Relationship between the Mean Surface Air Tem- perature over Egypt and NAO Index}

In general, the North Atlantic Oscillations are teleconnected with the climatic fluctuations over the northern Hemisphere [6,7,14,29-33]. For Egypt, Table 3 and Fig. (3) show the correlation coefficient between the seasonal and annual mean surface air temperature composite and the NAO index during the period 1948-2005. The results revealed that an existence of significant negative correlations between the seasonal mean surface air temperature and NAO. In addition to that, a significant negative correlation $(-0.6)$ has been found during winter season over south west part of Egypt ( 0.6 correlation means that only $36 \%$ of variance is explained). There are another two significant negative correlations $(-0.3)$ over most eastern part of Egypt during summer and autumn seasons $(0.3$ correlation means that only $9 \%$ of variance is explained). Meanwhile spring season characterized by weakness correlation. Generally, there are non-significant annual correlations $(+0.2)$ over North West and (-0.2) over south of Egypt.

\subsection{Relationship between the Mean Surface Air Tem- perature over Egypt and ENSO}

The correlation coefficient between the seasonal and annual mean surface air temperature composite and EL-Nino3 and SOI have been studied over Egypt during the period 1948-2005. The results are tabulated in Tables $\mathbf{4}$ and $\mathbf{5}$ and illustrated by Figs. (4,5). However, Table 4 and Fig. (4) show the correlation coefficient between the seasonal and annual mean surface air temperature composite and ELNino3 while Table 5 and Fig. (5) show the correlation coefficient of air temperature with SOI over Egypt during the period 1948-2005. It is noticed that there is only one distinct significant correlation value of $(+0.6)$ between surface air temperature and EL-Nino3 during autumn season over south western part. Meanwhile the values of correlation coefficients are non significant over other parts of Egypt.

In addition to that, it is observed from Table 5 and Fig. (5) that, the correlation values arranged between- 0.5 and +0.3 . Also, there existed two outstanding significant values of correlations. First one with negative correlation $(-0.5)$ has been found for autumn season over south west part while, second one has positive correlation $(+0.3)$ observed for winter season over south east part. Other seasons have non-significant correlation values arranged between- 0.2 and +0.1 over the other parts of Egypt.

Table 3. The Correlation Coefficient between the Seasonal and Annual Mean Surface Air Temperature Composite over Egypt and the NAO Index during the Period 1948-2005

\begin{tabular}{|c|c|c|c|c|}
\hline \multicolumn{2}{|c|}{ Negative Correlation } & \multicolumn{2}{c|}{ Positive Correlation } & \multirow{2}{*}{ Correlation Season } \\
\hline Location in Egypt & NAO Index & Location in Egypt & NAO index & Winter \\
\hline \hline South West & $-0.6^{*}$ & --- & - & Spring \\
\hline East to Middle & -0.2 & South & +0.1 & Summer \\
\hline East & $-0.3^{*}$ & North West & --1 & Autumn \\
\hline North East and South East & $-0.3^{*}$ & --- & +0.2 & Annual \\
\hline South & -0.2 & North West & & \\
\hline
\end{tabular}

(---) Means that there is no positive correlation.

(*) Means that there is a significant level $>95 \%$. 
(a)

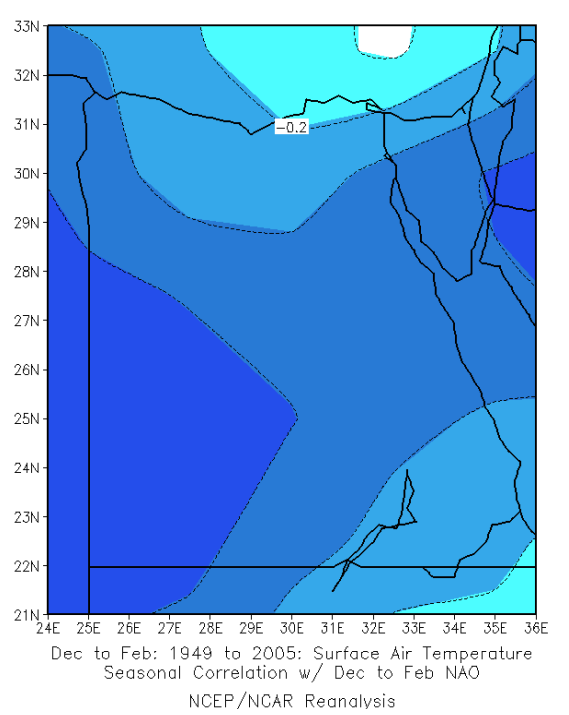

(c)

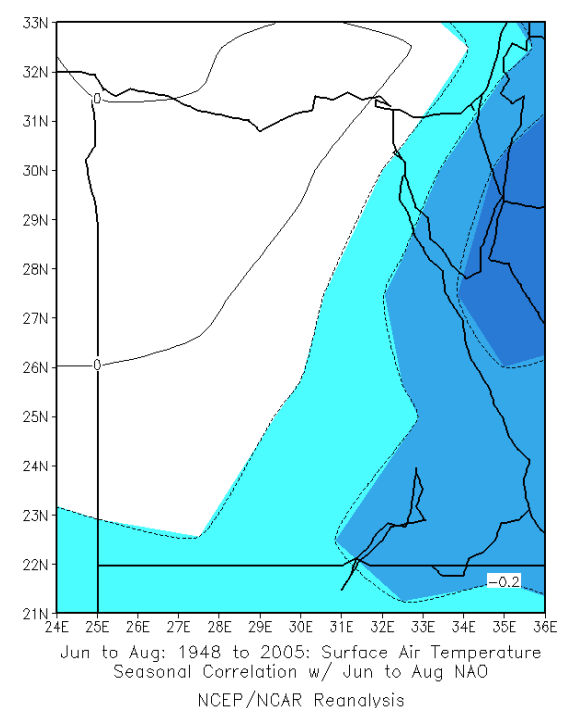

(b)

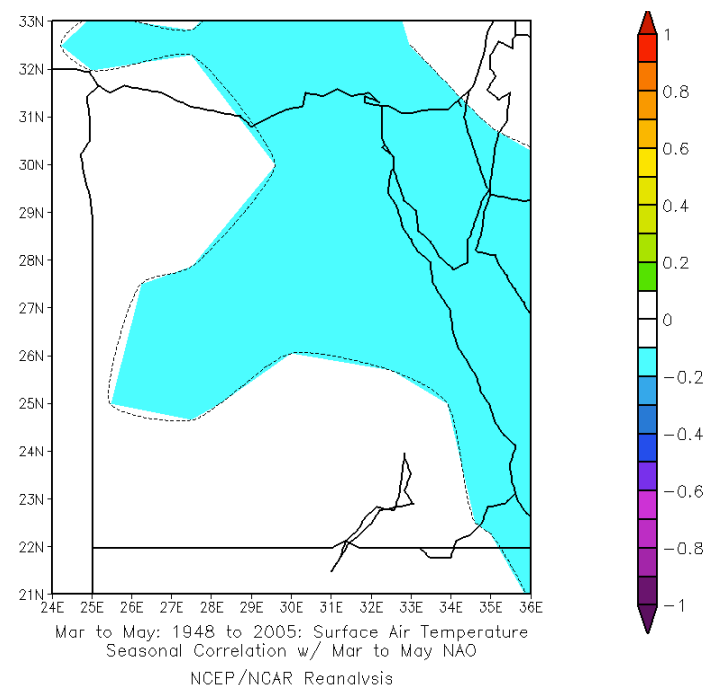

(d)

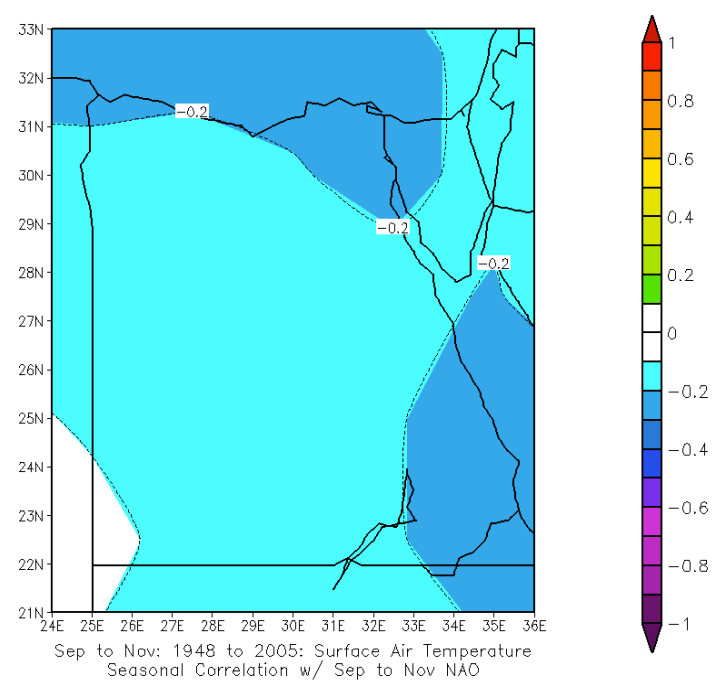
NCEP/NCAR Reanalysis

(e)

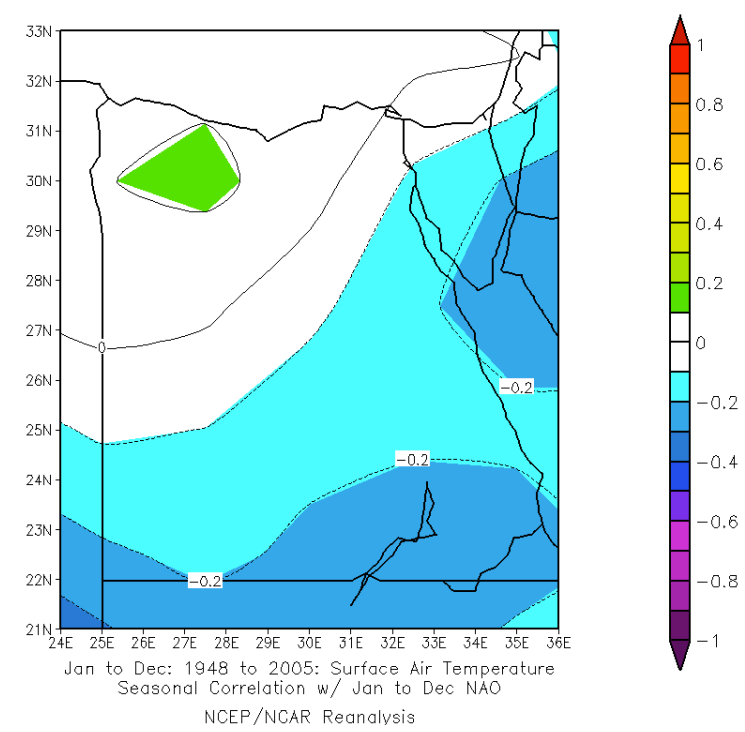

Fig. (3). The distribution of seasonal and annual correlation coefficient between the mean surface air temperature $\left({ }^{\circ} \mathrm{C}\right)$ over Egypt and NAO index during the period 1948-2005. (a) Winter, (b) Spring, (c) Summer, (d) Autumn and (e) Annual. 
Table 4. The Correlation Coefficient between the Seasonal and Annual Mean Surface Air Temperature Composite and EL-Nino3 over Egypt during the Period 1948-2005

\begin{tabular}{|c|c|c|c|c|}
\hline \multicolumn{2}{|c|}{ Negative Correlation } & \multicolumn{2}{c|}{ Positive Correlation } & \multirow{2}{*}{ Correlation Season } \\
\hline Location in Egypt & EL-Nino3 & Location in Egypt & +0.1 & Winter \\
\hline \hline South East & -0.2 & All Egypt except South East & -- & Spring \\
\hline All Egypt & -0.2 & -- & +0.2 & Summer \\
\hline North and East & -0.1 & South West & $+0.6^{*}$ & Autumn \\
\hline--- & -- & South West & Annual \\
\hline All Egypt except South West & -0.1 & South West & +0.2 & \\
\hline
\end{tabular}

(---) Means that there is no positive correlation.

(*) Means that there is a significant level $>95 \%$

\section{DISCUSSION AND CONCLUSION}

The present paper is a trial to investigate the relationship between the mean surface air temperature in Egypt and NAO index and SOI and E1 Nino3 using of the NCEP/NCAR reanalysis monthly data for the period (1949-2005). The anomalies methodology has been used to clarify the seasonal and annual warming and cooling parts of Egypt. However, the Monte Carlo methodology has been used to obtain the correlation coefficient values between the mean surface air temperature in Egypt and NAO index and ENSO. The results revealed that, the distribution of the seasonal and annual surface air temperature varies from season to season and from part to part over Egypt. Whereas, the ranges of seasonal air temperature value are $\left(11\right.$ and $\left.19^{\circ} \mathrm{C}\right),\left(18\right.$ and $\left.26^{\circ} \mathrm{C}\right),(25$ and $\left.33^{\circ} \mathrm{C}\right)$, $\left(20\right.$ and $\left.28^{\circ} \mathrm{C}\right)$, and $\left(20\right.$ and $\left.27^{\circ} \mathrm{C}\right)$ during winter, spring, summer, autumn and annual respectively. It is clear that the range interval between the minimum and maximum mean surface temperature is much closed values for the four seasons and annual. In addition to that the annual distribution of mean surface temperature is near to the autumn distribution features. From anomalies analysis of the surface temperature over Egypt, there is a distinct warming over most of the southern parts while the northern parts are characterized by existence of cooling. The maximum warming $\left(+1.2^{\circ} \mathrm{C}\right)$ has been found during both summer and autumn seasons over south and south-west parts respectively. Meanwhile, the maximum cooling $\left(-0.4^{\circ} \mathrm{C}\right)$ has been found during winter season over north and east parts. Furthermore, the annual mean of maximum positive anomalies $\left(+0.8^{\circ} \mathrm{C}\right)$ is obtained over the southern part. These results revealed that there is a warming in the southern meanwhile cooling in the northern parts of Egypt. In fact Egypt lies under influence of two different weather regimes. Northern parts follow the Mediterranean regime and the southern parts are following the subtropical regime. The correlation coefficient between the seasonal and annual mean surface air temperature composite and NAO, SOI, and El-Nina3 have been analyzed over Egypt during the period 1948-2005. A significant negative correlation (-0.6) has been found between NAO index and mean surface air temperature over south west part of Egypt during winter season. Meanwhile, this correlation has been found non significant for the other parts of Egypt during spring, summer and autumn seasons. This result reflects the influence of $\mathrm{NAO}$ on the weather regime in the northern part of Egypt in wintertime. There is only one distinct significant correlation value of $(+0.6)$ between surface air temperature and EL-Nino3 during autumn season over south western part. This significant correlation in autumn may be clarified in the light of, the interaction between the tropical and subtropical weather regimes at the south western part of Egypt more active in autumn seasons. Whereas the anomalies study of surface temperature shows a worming in the southern part of Egypt, and as known the El-Nino becomes more frequent in the last decades. For the correlation values arranged between- 0.5 and +0.3 . Also, there existed two outstanding significant values of correlations. First one with negative correlation $(-0.5)$ has been found for autumn season over south

Table 5. The Correlation Coefficient between the Seasonal and Annual Mean Surface Air Temperature Composite and the SOI over Egypt during the Period 1948-2005

\begin{tabular}{|c|c|c|c|c|}
\hline \multicolumn{2}{|c|}{ Negative Correlation } & \multicolumn{2}{c|}{ Positive Correlation } & \multirow{2}{*}{ Correlation Season } \\
\hline Location in Egypt & SOI & Location in Egypt & $+0.3^{*}$ & \multirow{2}{*}{ Winter } \\
\hline \hline West & -0.1 & South East & +0.1 & Spring \\
\hline North East to Middle & -0.1 & South and North West & +0.1 & Summer \\
\hline South West & -0.2 & South East & +0.1 & +0.1 \\
\hline South West & $-0.5^{*}$ & South East & Autumn \\
\hline West & -0.2 & South East & Annual \\
\hline
\end{tabular}

(*) Means that there is a significant level $>95 \%$. 
(a)

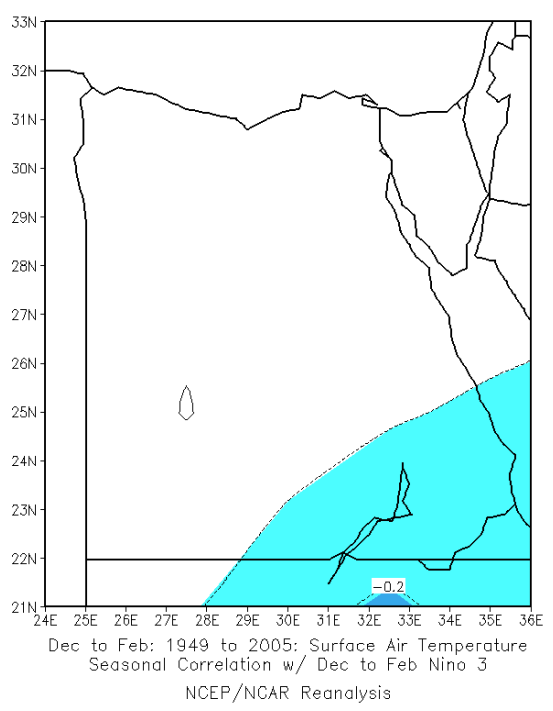

(c)

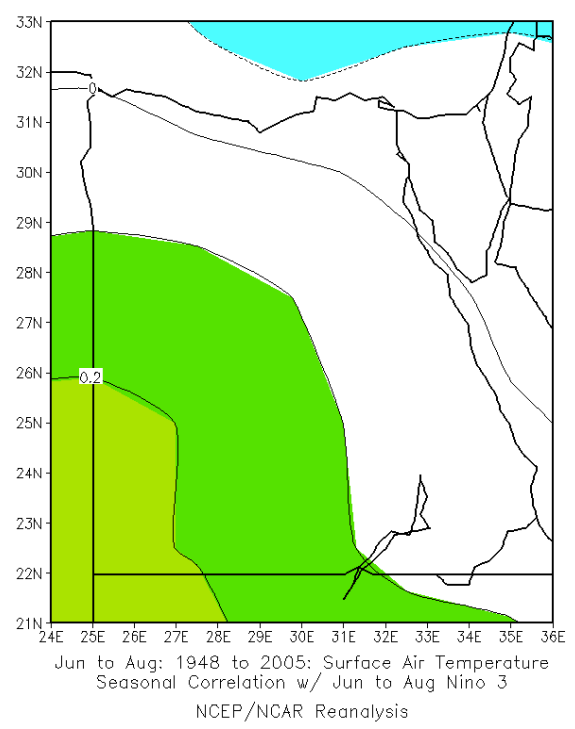

(b)

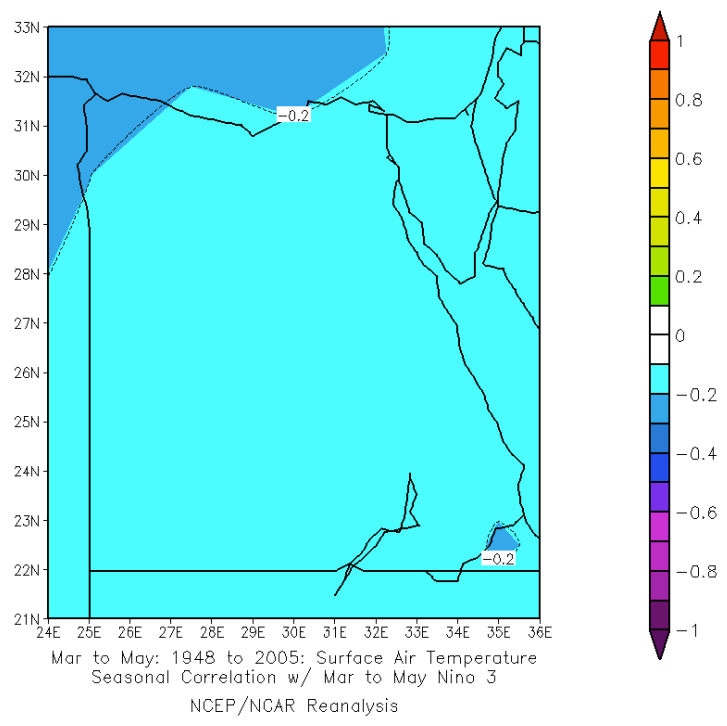

(d)

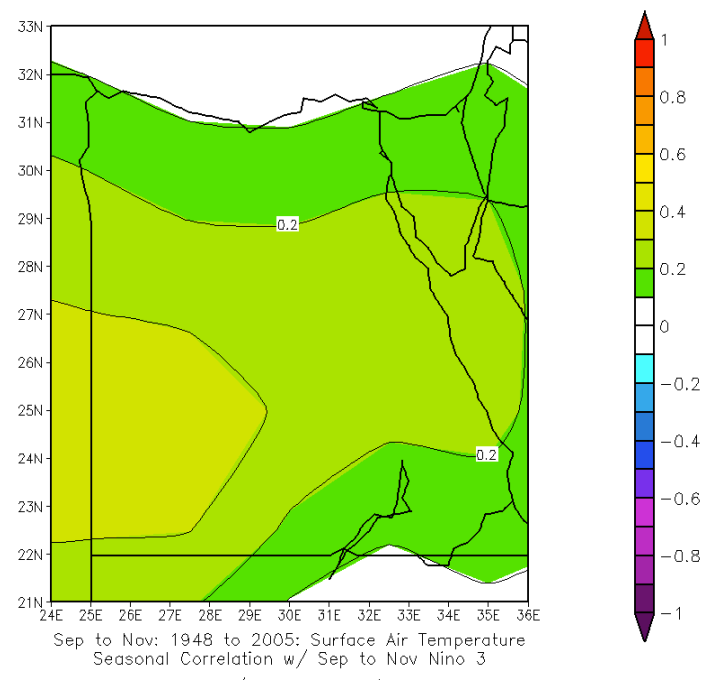

NCEP/NCAR Reanalysis

(e)

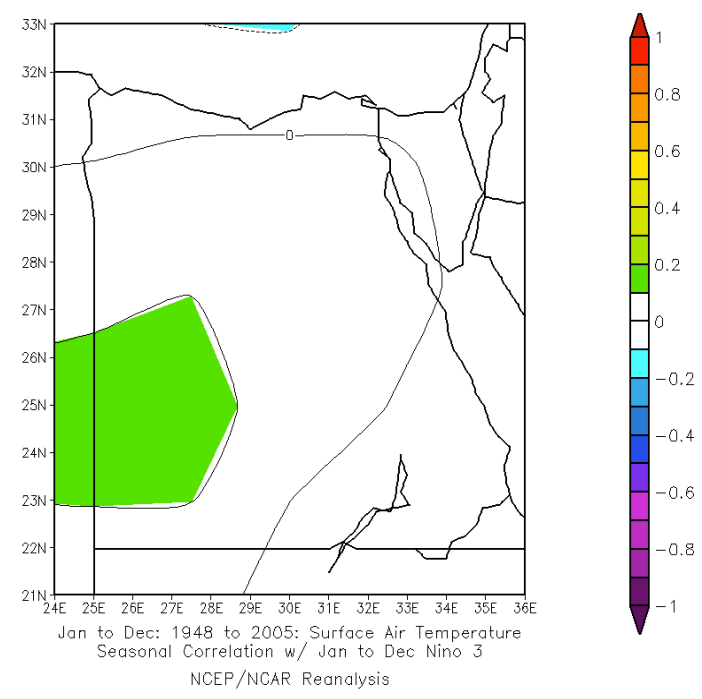

Fig. (4). The distribution of seasonal and annual correlation coefficient between the surface air temperature $\left({ }^{\circ} \mathrm{C}\right)$ over Egypt and EL-Nino3 during the period 1948-2005. (a) Winter, (b) Spring, (c) Summer, (d) Autumn and (e) Annual. 
(a)

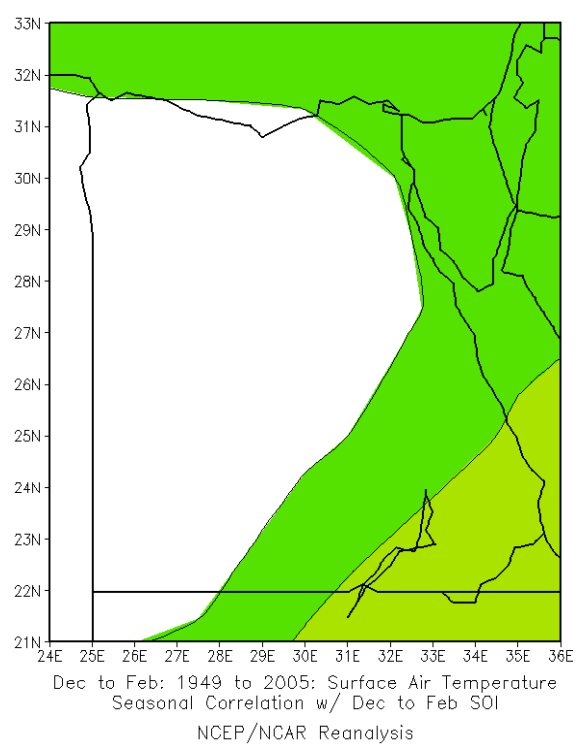

(c)

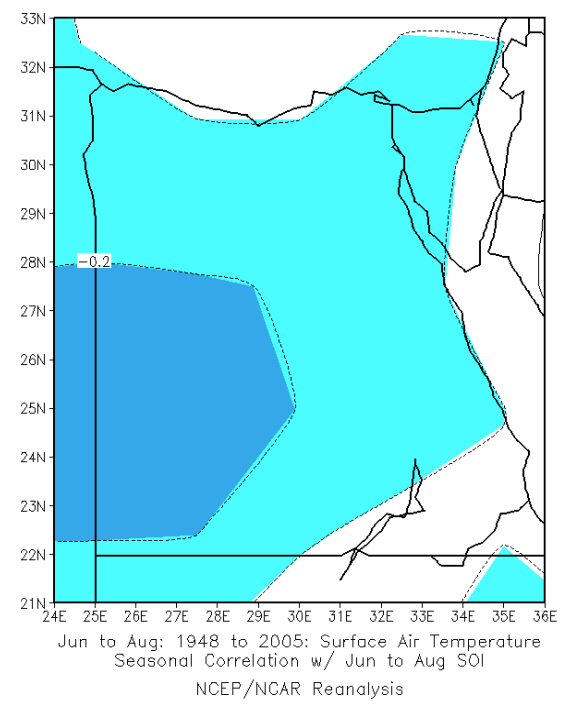

(b)

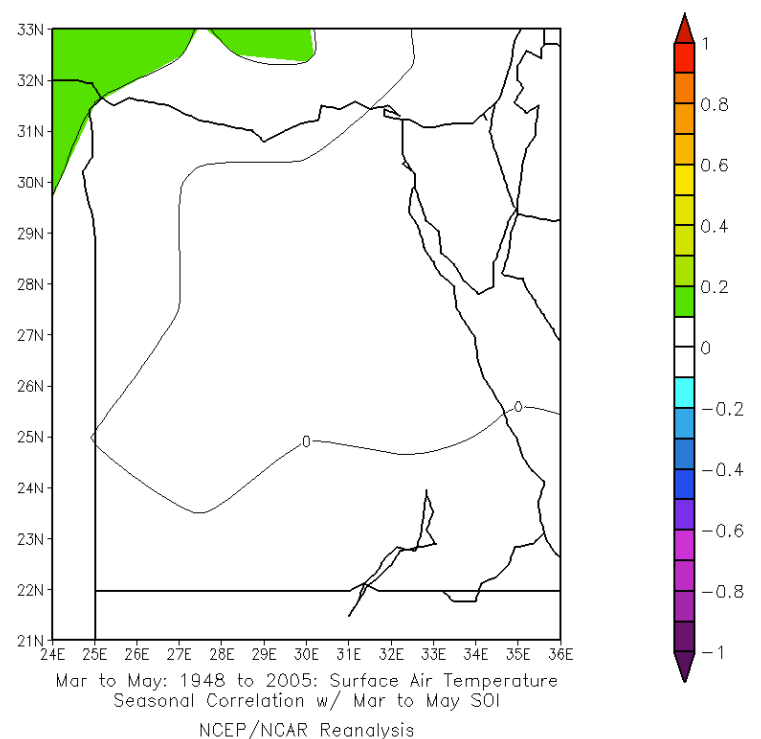

(d)

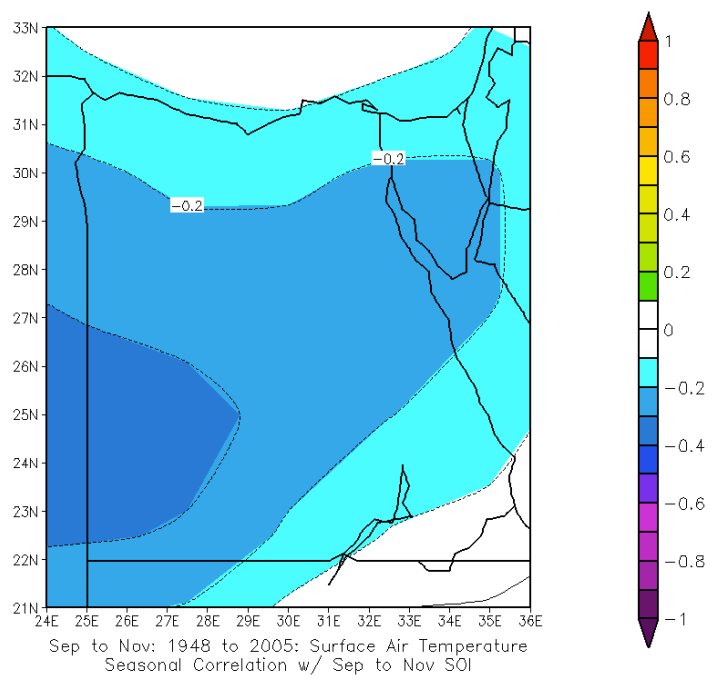

NCEP/NCAR Reanalysis

(e)

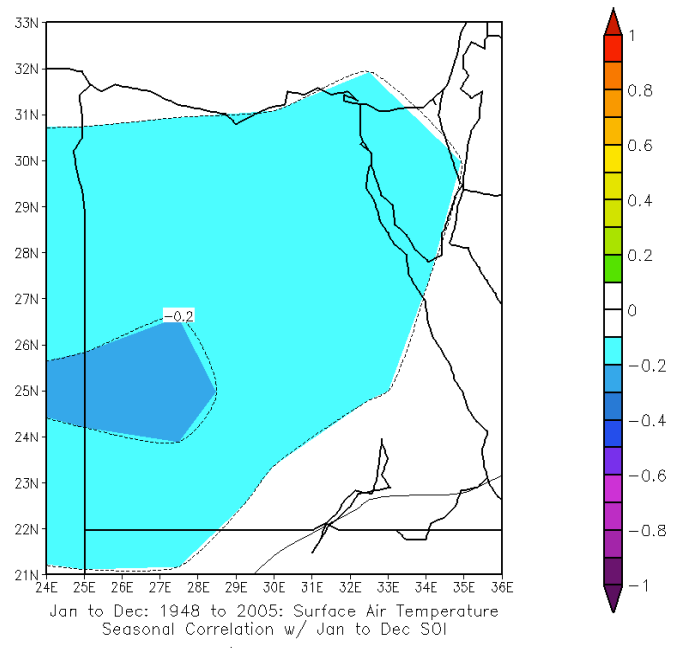

NCEP/NCAR Reanalysis

Fig. (5). The distribution of seasonal and annual correlation coefficient between the mean surface air temperature $\left({ }^{\circ} \mathrm{C}\right)$ over Egypt and SOI during the period 1948-2005. (a) Winter, (b)Spring, (c) Summer, (d) Autumn and (e) Annual. 
west part while second one has positive correlation $(+0.3)$ observed for winter season over south east part. Meanwhile, a significant negative correlation $(-0.4)$ between SOI and the mean surface air temperature for autumn season has been found also over south west part of Egypt. One can concluded that, the correlation coefficient study, clarify that although the climatic indices NAO and ENSO influence the regional climate for several parts in the globe (as shown from severely lecturers) the results of the present work revealed that the relationship between NAO index and ENSO and the mean surface air temperature is significant for only limited area of Egypt. These results may explained by the fact that the mean surface temperature in northern coast of Egypt affected by the strong phase of NAO that occurs only in wintertime. Meanwhile, the temperature in southern parts of Egypt affected by the southern tropical oscillations represented in SOI and El-Nino3 particularly in autumn season.

\section{ACKNOWLEDGEMENTS}

Authors present greet thanks to the referees for comments and valuable suggestions. The authors would like to express their deep gratitude to the Earth System Research Laboratory, for the datasets and images that are used in the present study. These datasets and images have been provided by the NOAA/ESRL Physical Sciences Division, Boulder Colorado, USA, from their Web site at http: //www.cdc. noaa.gov/.

\section{REFERENCES}

[1] Rogers JC. Atmospheric circulation changes associated with the warming over the northern North Atlantic in the 1920s. J. Climate Appl Meteor 1985; 24: 1303-10.

[2] Rogers JC, McHugh M. On the separability of the North Atlantic Oscillation and Arctic Oscillation. Clim Dyn 2002; 19: 599-608.

[3] Barnston A, Livezey RE. Classification, seasonality and persistence of low-frequency circulation patterns. Mon Wea Rev 1987; 115: 1083-126.

[4] Hurrell JW. Decadal trends in the North Atlantic Oscillation: Regional temperatures and precipitation. Science 1995; 269: 676-9.

[5] Ambaum MH, Hoskins B, Stephenson DB. Arctic Oscillation or North Atlantic Oscillation? Climate 2001; 14: 3495-507.

[6] Hurrell JW. Influence of variations in extratropical wintertime teleconnections on Northern Hemisphere temperature. Geophys Res Lett 1996; 23: 665-8.

[7] Hurrell JW, Kushnir Y, Ottersen G, Visbeck M. An Overview of the North Atlantic Oscillation. In: Hurrell JW, Kushnir Y, Ottersen G, Visbeck M, Ed. The North Atlantic Oscillation: Climatic Significance and Environmental Impact. Washington D.C.: American Geophysical Union. 2003; pp. 279+vii. 301-326.

[8] Hastenrath J. Variations in low-latitude circulation and extreme climatic events in the tropical Americas. J Atmos Sci 1976; 33: 205-15.

[9] Ropelewski CF, Halpert MS. Global and regional scale precipitation patterns associated with the El Nino/Southern Oscillation. Mon Wea Rev 1987; 115: 1606-26.

[10] Price C, Stone L, Huppert A, Rajagopalan B, Alpert P. A Possible Link Between El Nino and Precipitation in Israel. Geophys Res Lett 1998; 25: 3963-3966.
[11] Diaz HF, Markgraf V. (eds.). El Nino and the Southern Oscillation, Multiscale Variability and Global and Regional Impacts. Cambridge: Cambridge University Press, 2000; pp. 496.

[12] Trenberth KE, Caron JM. The Southern Oscillation Revisited: Sea Level Pressures, Surface Temperatures, and Precipitation. J Climate $2000 ; 13(24)$ : 4358-65.

[13] Trenberth KE. The definition of El Niño. Bull Amer Meteor Soc 1997; 78: 2771-7.

[14] Malmgren BA, Winter A, Chen D. El-Nino-Southern Oscillation and North Atlantic Oscillation control of climate in Puerto Rico. J Climate 1998; 11: 2713-7.

[15] Hafez YY, Hasanean HM. The Variability of Wintertime Precipitation in the Northern Coast of Egypt and Its Relationship with the North Atlantic Oscillation. AMS, Proceeding of the 12th Symp on Global Change and Climate Variations, 14-18 January, 2001, Albuquerque, New Mexico, USA, 2001; pp. 330-3.

[16] Hasasnean HM. Wintertime surface temperature in Egypt in relation to the associated atmospheric circulation. Int J Climatol 2004; 24: 985-99.

[17] Hafez YY. The connection between the 500 hpa geopotential height anomalies over Europe and the abnormal weather in eastern Mediterranean during winter 2006. I. J. Meteorology, UK, 2007; 32(324): 335-43.

[18] Rasmusson EM, Carpenter TH. Variations in tropical sea surface temperature and surface wind fields associated with the Southern Oscillation/El Niño. Mon Wea Rev 1982; 110: 354-84.

[19] Rasmusson EM, Carpenter TH. The relationship between eastern equatorial Pacific sea surface temperature and rainfall over India and Sri Lanka. Mon Wea Rev 1983; 111: 517-28.

[20] Schonher T, Nicholson SE. The Relationship between California Rainfall and ENSO Events. J Climate 1989; 2: 1258-69.

[21] Cane MA, Eshel G, Buckland RW. Forecasting Zimbabwean maize yield using eastern equatorial Pacific sea surface temperature. Nature 1994; 370: 204-5.

[22] Yakir D, Lev-Yadun S, Zangvil A. El Nino and tree growth near Jerusalem over the last 20 years. Glob Change Biol 1996; 2: 101-5.

[23] Zhang Y, Wallace JM, Iwasaka N. Is climate variability over the North Pacific a linear response to ENSO? J Climate 1996; 9: 146878.

[24] Trenberth KE, Hoar TJ. El Nino and climate change. Geophys Res Lett 1997; 24: 3057-60.

[25] Straus DM, Shkula J. Variations of midlatitude transient dynamics associated with ENSO. J Atmos Sci 1997; 54: 777-90.

[26] Kalnay E, Kanamitsu M, Kistler R, et al. The NCEP/NCAR 40year reanalysis project. Bull Am Meteorol Soc 1996; 77: 437-71.

[27] Philips JL. How to Think About Statistics (W.H. Freeman, New York), 5th ed., 1996; pp.191

[28] Livezey RE, Chen WY. Statistical field significance and it's determination by Monte Carlo Techniques. Mon Wea Rev 1983; 111: 46-59.

[29] Wallace JM, Gutzler DS. Teleconnections in geopotential height field during the Northern Hemisphere winter. Mon Wea Rev 1981; 109: 784-812.

[30] Hurrell JW, van Loon H. Decadal variations in climate associated with the North Atlantic oscillation. Clim Change 1997; 36: 301326.

[31] Lu J, Greatbatch RJ. The changing relationship between the NAO and Northern Hemisphere climate variability. Geophys Res Lett 2002; 29(7): 1148 .

[32] Kodera K, Kuroda Y. Regional and hemispheric circulation patterns in the Northern Hemisphere winter, or the NAO and the AO. Geophys Res Lett 2003; 30(18): 1934.

[33] Kodera K, Kuroda Y. Two teleconnection patterns involved in the North Atlantic/Arctic Oscillation. Geophys Res Lett 2004; 31: L20201. 